\title{
Traditional Yemeni Architecture and Its Impact on Energy Efficiency
}

\author{
Mohamed reda Abdallah', Hassan Ahmed Hassan², Ali Abbas al-Olofi ${ }^{3}$ \\ ${ }^{1}$ Professor of Architecture and Building Technology, Architecture Department, Faculty of Engineering, Cairo University, Egypt. \\ ${ }^{2}$ Assistant Professor, Architecture Department, Faculty of Engineering, Institute of Aviation Engineering and Technology, Egypt. \\ ${ }^{3}$ Teacher Assistant, Architecture Department, Faculty of Engineering, Institute of Aviation Engineering and Technology, Egypt.
}

\begin{abstract}
:
The ancestors 'interaction in the past with the surrounding environment and natural resources was part of the way they stay on this land in harmony, where the optimal use of resources to adapt to climatic conditions, therefore the sustainability for them by acclimatization and coexistence with the surrounding environment, so it was spontaneous in the dealings of ancestors with the environment, and did not It was random at the same time, but was based on the inheritance of those experiences through learning through the principle of "trial and error", so traditional architecture was designed in the past to be sustainable architecture in an indirect way (it grows from nature and when the building's life cycle ends, the building's resources decompose and return to nature without any negative impact on it). The research aims to study the types of buildings in Yemeni architecture that have appeared in different urban environments and regions in Yemen through an analytical study of techniques, methods and architectural elements of some buildings and their impact on energy efficiency, then focus on analyzing and studying
\end{abstract}

the environmental components of the traditional sana'ani building by studying and understanding the environmental elements For buildings. Consequently, we find that Yemen is one of the few countries that have preserved these characteristics over hundreds of years, dependent on their local natural resources and integrated with the environment.

Key words: Yemeni architecture - energy efficiency.

\section{TRADITIONAL LOCAL \\ YEMENI ARCHITECTURE}

The traditional Yemeni architecture differed in its different natural, climatic and geographical components from one region to another, according to the requirements of the building and the surrounding environmental life in the different regions, which can be divided based on the natural resources and materials available for construction in different regions, as well as the terrain that varied from one region to another[1].(Table.1).

Table 1: Yemeni architecture in different regions. Source: Authors.

\begin{tabular}{|c|c|c|c|}
\hline & $\begin{array}{l}\text { Mountain regions } \\
\text { architecture }\end{array}$ & Desert regions architecture & Coastal regions architecture \\
\hline 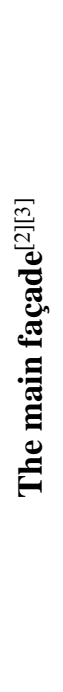 & 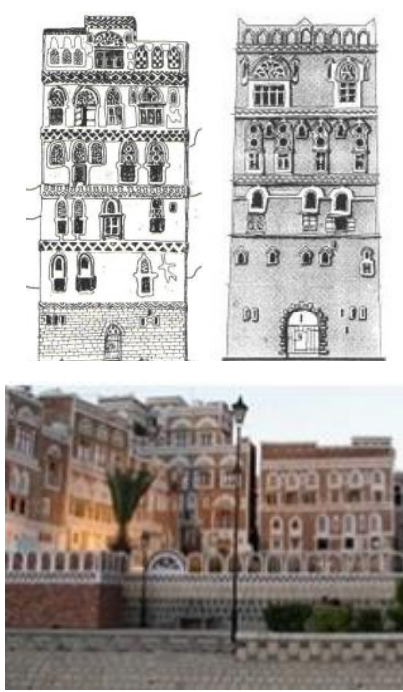 & 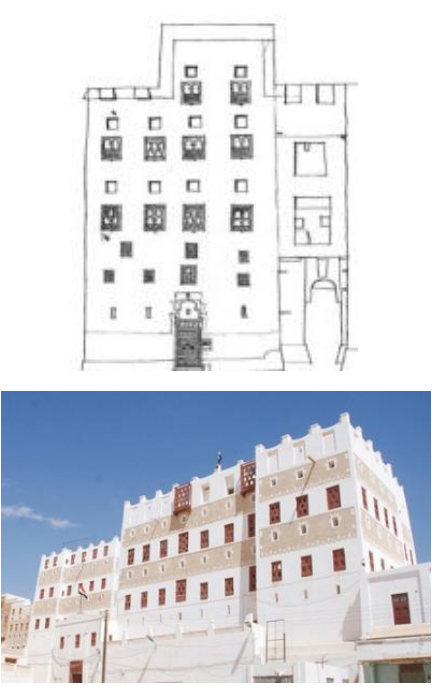 & 4 \\
\hline
\end{tabular}


International Journal of Engineering Research and Technology. ISSN 0974-3154, Volume 13, Number 8 (2020), pp. 2014-2022

(C) International Research Publication House. https://dx.doi.org/10.37624/IJERT/13.8.2020.2014-2022

\begin{tabular}{|c|c|c|c|}
\hline 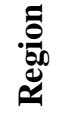 & Sana'a & ShibamHadramout & Tehama \\
\hline 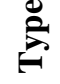 & Tower building & Tower building & A courtyard house \\
\hline 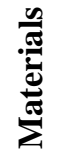 & Stone, Mud brick, clay & Dried bricks (clay), gypsum & $\begin{array}{l}\text { Mud brick, Clay, palm } \\
\text { branches, gypsum }\end{array}$ \\
\hline 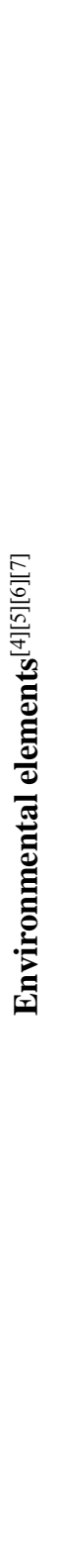 & $\begin{array}{l}\text { Building thick walls of mud } \\
\text { bricks, as it works as a } \\
\text { thermal filter by using } \\
\text { thermal convection delay } \\
\text { and internal heat } \\
\text { preservation } \\
\text { - Use wood as breakers in the } \\
\text { windows, to prevent cold air } \\
\text { at night, and reduce thermal } \\
\text { gain in summer. } \\
\text { - Use white and light colors } \\
\text { in the external finishes, } \\
\text { which reflect the sunlight } \\
\text { from the facades of the } \\
\text { building and not absorbed. } \\
\text { - Using the garden (Al- } \\
\text { Bustan) as a courtyard open } \\
\text { to the surrounding } \\
\text { buildings, where it works as } \\
\text { a thermostat that softens the } \\
\text { atmosphere and creates } \\
\text { balance in temperature. } \\
\text { The use of Mashrabiya in } \\
\text { the upper floors to reduce } \\
\text { designed to meet the } \\
\text { bunlight and to control } \\
\text { ventilation. } \\
\text { regulate the heat inside the } \\
\text { building and reduce the heat } \\
\text { load in the summer. } \\
\text { well as the arion and lighting, as } \\
\text { - } \\
\text { - }\end{array}$ & $\begin{array}{l}\text { The difference in height and } \\
\text { regularity of buildings } \\
\text { helped to provide shadows } \\
\text { between buildings, and to } \\
\text { reduce the external climate } \\
\text { impacts. } \\
\text { - Use clay as a thick outer } \\
\text { covering achieves thermal } \\
\text { insulation and provides a } \\
\text { suitable internal thermal } \\
\text { environment. } \\
\text { - Use white plaster to cover } \\
\text { the ceiling and external } \\
\text { walls, to reflect sunlight and } \\
\text { prevent heat gain. } \\
\text { Irregular streets were used } \\
\text { to reduce the impact of the } \\
\text { wind, and the courtyards } \\
\text { were used to ventilate and } \\
\text { soften the atmosphere inside } \\
\text { the building. } \\
\text { - The openings consisted of } \\
\text { upper and lower parts, so } \\
\text { that the air was moved using } \\
\text { the pressure difference. } \\
\text { to protect the openings from } \\
\text { direct sunlight, provide } \\
\text { natural light, and benefit } \\
\text { from natural ventilation. }\end{array}$ & $\begin{array}{l}\text { - Narrow streets, providing } \\
\text { shade space, and reducing } \\
\text { hot winds in summer. } \\
\text { - Use mud bricks to build } \\
\text { double walls, to protect the } \\
\text { building from the effects of } \\
\text { the external climate. } \\
\text { - Use white plaster to cover } \\
\text { the ceiling and external } \\
\text { walls, to reflect sunlight and } \\
\text { prevent heat gain. } \\
\text { - Use a patio as a thermostat, } \\
\text { which opens up the building } \\
\text { voids. } \\
\text { - The openings consisted of } \\
\text { upper and lower parts, so } \\
\text { that the air was moved using } \\
\text { the pressure difference. } \\
\text { - Use the wooden mashrabiya } \\
\text { to protect the openings from } \\
\text { direct sunlight, provide } \\
\text { natural light, and benefit } \\
\text { from natural ventilation. }\end{array}$ \\
\hline
\end{tabular}

\section{THE TRADITIONAL SANA'ANI BUILDING}

The tower buildings are the predominant in the old city of Sanaa, and they are considered one of the most important features of the city, where the buildings appeared as a continuous block forming the sky line in harmony with the surrounding mountainous nature, and these buildings were built from 4-9 floors according to the need[8].(Figure 1,2) shows the traditional buildings in old sana'a. 


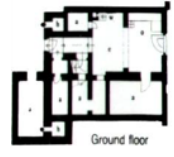

ground floor

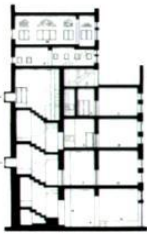

section

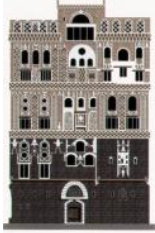

Elevation

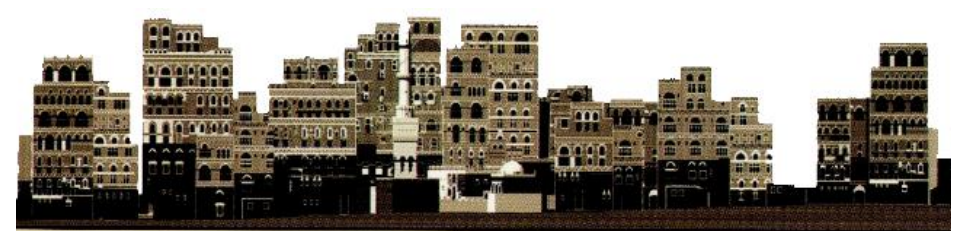

Sky line in the old city of Sana'a

Fig 1. Traditional tower buildings in old Sana'a[8].

\section{II.I. Local building materials:}

The architectural elements in the local Sana'ani architecture contributed to reducing energy consumption, whether at the stage of manufacture, installation or maintenance, and when the building is ends, the materials return to nature (such as stone, mud bricks, clay)[9], and wood was also used in the ceilings and windows, as it performs good insulation In the external weather in winter and summer through the building envelope [4], gypsum has been used in the interior finishes, as it has proven to be anti-rot and does not allow the growth of fungi and harmful microorganisms on it, and all of these materials are characterized by the possibility of reuse again after the end of the building[10] (Fig. 3).
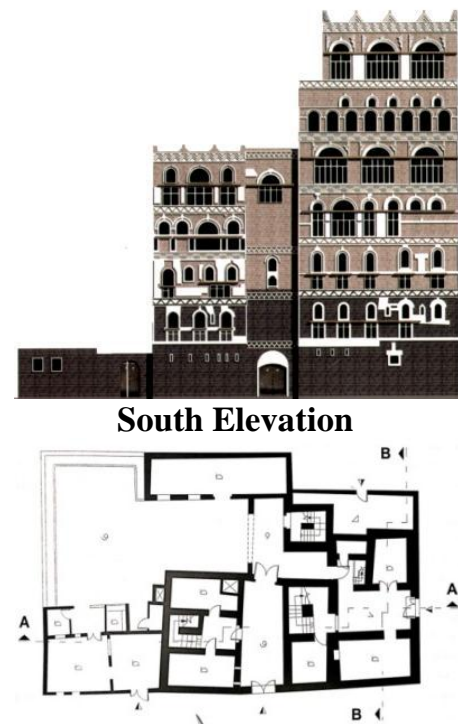

Ground Floor Plan

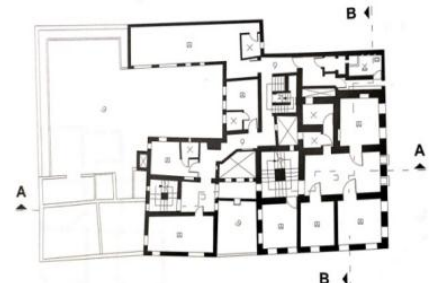

Second Floor Plan

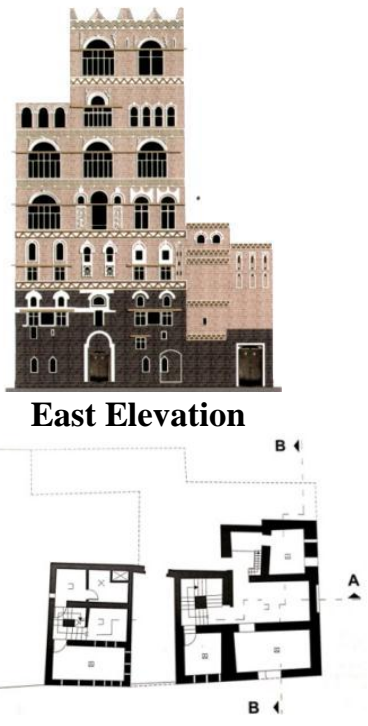

Mezzanine Floor Plan

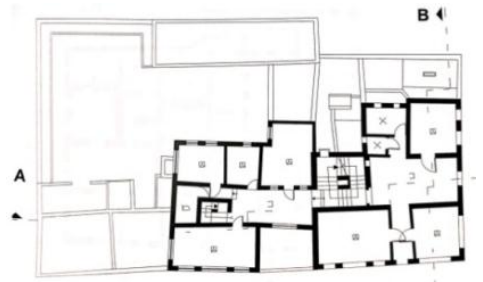

ThirdFloor Plan

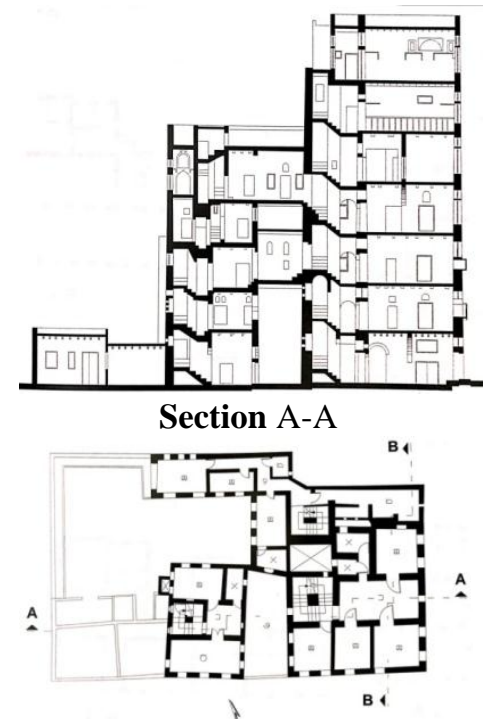

First Floor Plan

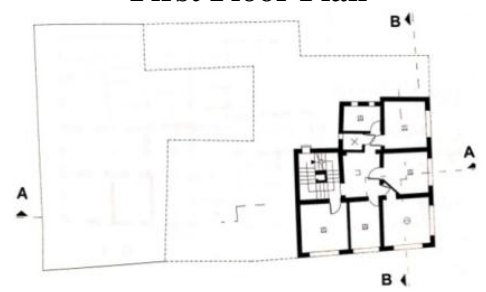

FourthFloor Plan

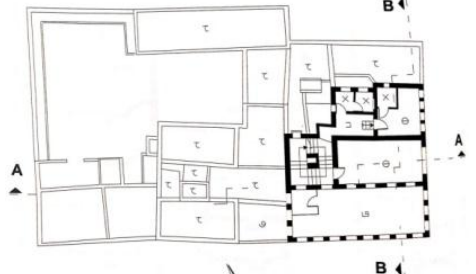

FifthFloor Plan

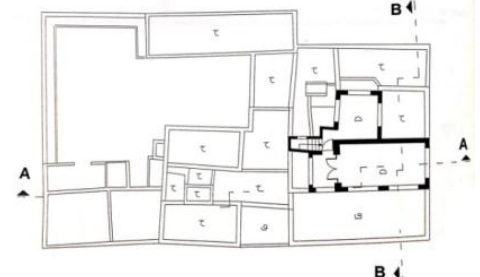

Sixth Floor Plan

Fig 2. Design of a traditional building in old Sana'a [8]. 


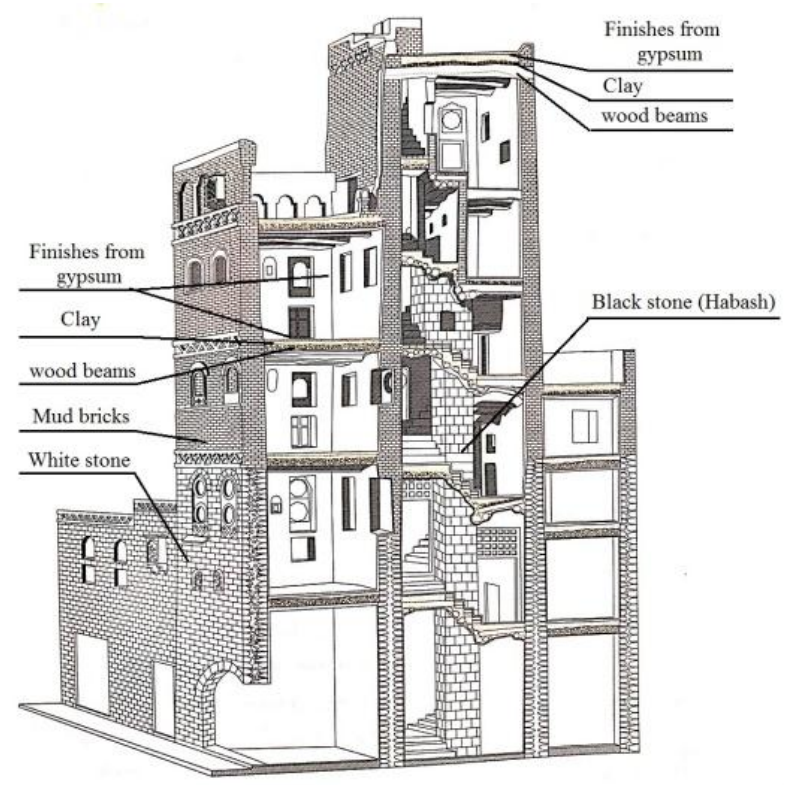

Fig.3: A section showing the building materials for the traditional Sana'ani building [8].

\section{II.II. Building form}

- The orientation in traditional tower house to the south.

- The thermal gain of tower buildings is more than small ones in winter, where most of the walls are exposed to solar radiation and heat gain in winter, and the area exposed to solar radiation in building decreases in summer, therefore the temperature decreases in repeated floors.

- The long axis of shape tower building extends from east to west, which means that long side of building is facing north and south, this allows placing most of windows in northern and southern walls. As a result building can control solar thermal for heating and cooling in summer and winter months[11] show(Fig.4).

- The shape in tower building was designed to create large areas for walls to increase thermal gain in winter, and reduce solar gain in summer due to size of ceiling relative to mass.

- The interior building design was based on primary and secondary spaces. The main spaces are oriented to south and used in winter, and the secondary spaces (spaces associated with movement, service) have been directed to north.

- Using the back yard (Al-Bustan)to soften atmosphere, create balance in temperature, and purify the air from dust [1].show (Fig.5).

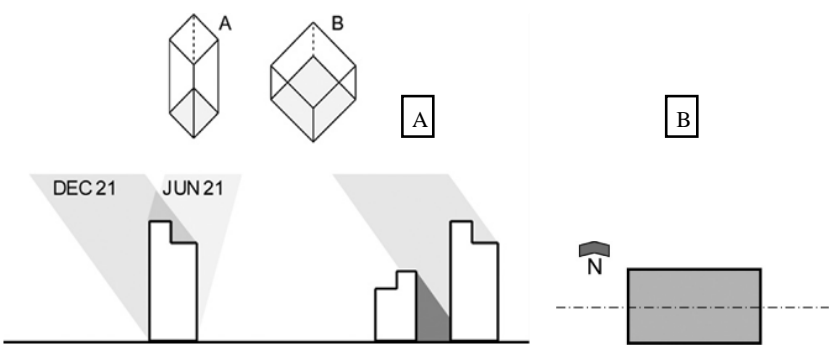

Fig.4:(A)The effect of the tower building shape on the thermal gain in winter and summer, (B) The axis of the elongation and the direction of the tower building [11].

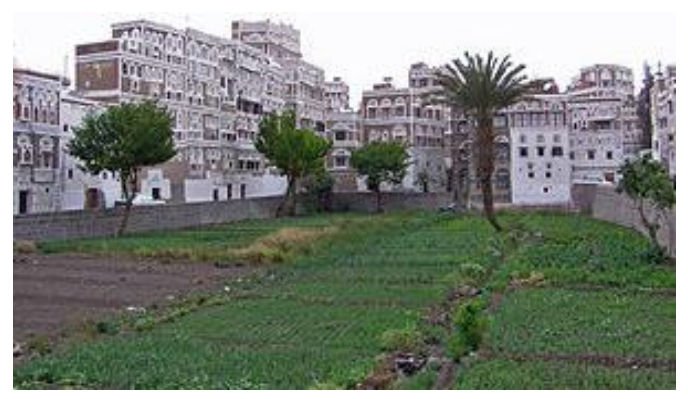

Fig.5: House back garden (Al-Bustan). Source: http://www.yementourism.com.

\section{II.III. Building envelope:}

The traditional tower building is built from local materials that do not allow warm currents to enter building during day or cold at night. The walls of southern building that have stored warmth are slowly lost during the night, and therefore traditional building provides thermal balance during entire day, as well as during seasonal changes across year [7]. The building envelope consists of the following: 
International Journal of Engineering Research and Technology. ISSN 0974-3154, Volume 13, Number 8 (2020), pp. 2014-2022

(C) International Research Publication House. https://dx.doi.org/10.37624/IJERT/13.8.2020.2014-2022

\section{II.III.I.Walls}

The walls are built with different thicknesses, where thickness of walls is $50 \mathrm{~cm}$ or more in lower floors, thickness of walls decreases whenever we go to top of building, and we notice difference of materials so the construction of e first floors is made of stones, as they are very hard and work as loadbearing walls for rest of floors, while upper floors are built of mud bricks Which works as a heat filter between internal and external thermal conditions, which is known as delay heat load and internal heat conservation, consequently providing a suitable thermal environment inside building[12].

\section{II.III.II.Ceiling:}

Local resources were a basic source in process of building roofs, so wood was used as beams that control width of rooms, walls, stairs, and use of branches trees linked, gathered on those wooden beams, they are covered with mud, which is part of the finishing work, then they are covered with white plaster, which reduces Thermal loads on the roofs [4].

\section{II.III.III.Openings:}

The openings appear different configurations in traditional tower building through organization, shape, as well as their location on the facade and their ratio in the wall (the relationship between the solid and voids), so the openings were affected by materials and construction methods, depending on use and functional need of building's space, and we note that openings are one part, which is the window Used to ventilate voids, provide natural light, and solar radiation entry, or two-part openings, the lower part is a window and upper part (Qamariah) work for lighting, and there are openings consisting of three parts, the third part is a small upper opening beside (Qamariah) used for ventilation, By taking advantage of temperature differences, which works to expel hot air, by effect of pressure differences [4].

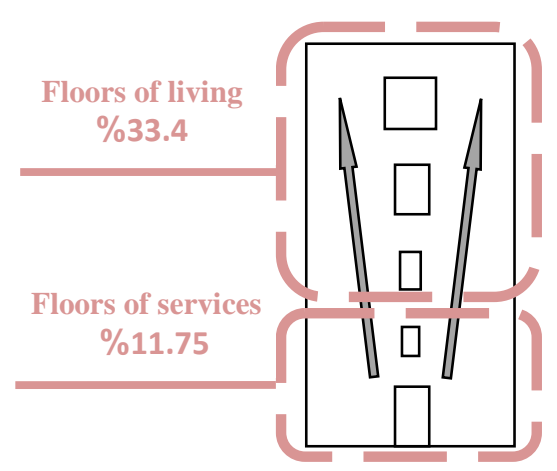

Fig.6:The size of the openings increases from bottom to the top.Source: Authors.

The ratio of Openings to solid for external walls:

The relationship of solid with open in tower building varies on different floors, according to functional and construction considerations. Most of buildings on first two floors are used for services and upper floors for living, and by studying these openings in building's envelope, we find that ratio of openings in main interface is sizes of openings are determined according to importance of directions and they come following order in terms of importance: the eastern, southern, western, and then northern facades (Fig.7).

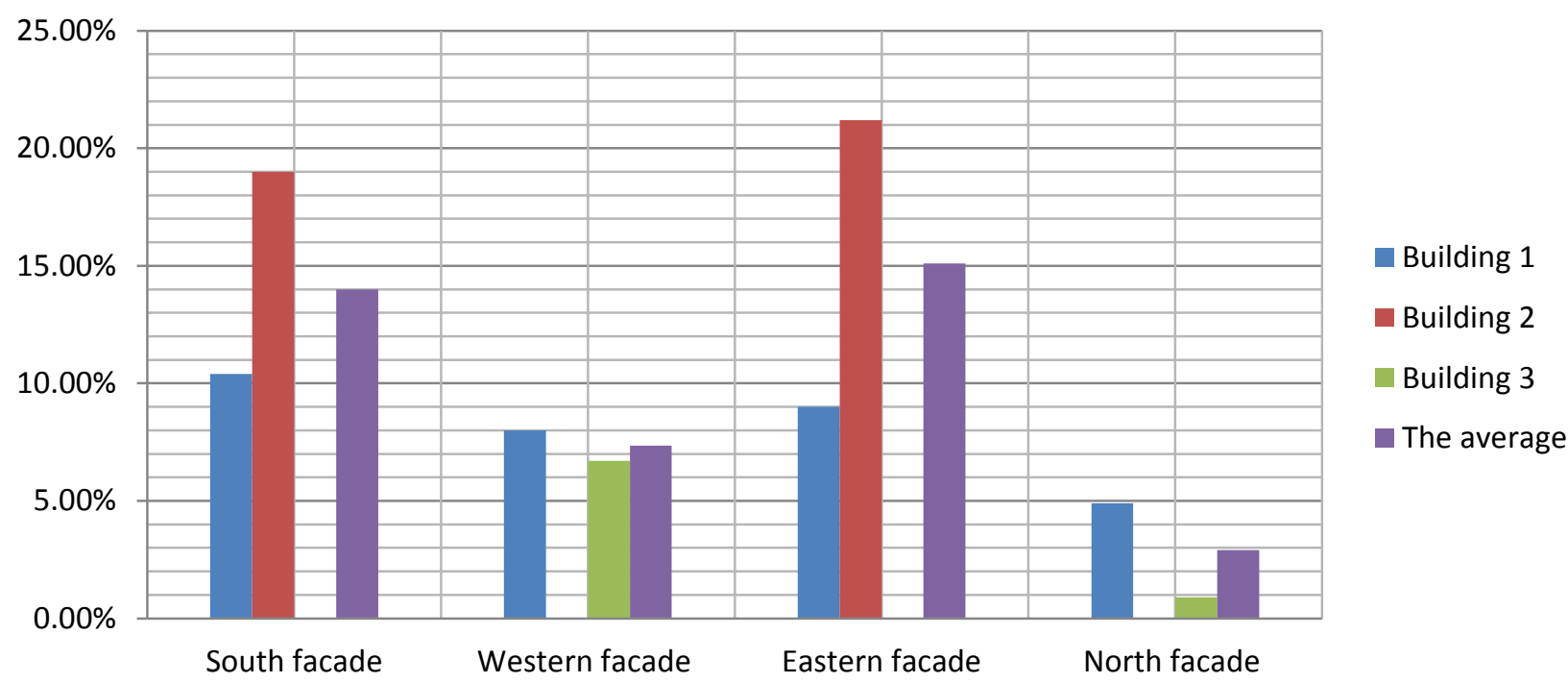

Fig.7: The ratio of openings in different facades of buildings. Source: Authors. 
International Journal of Engineering Research and Technology. ISSN 0974-3154, Volume 13, Number 8 (2020), pp. 2014-2022

(C) International Research Publication House. https://dx.doi.org/10.37624/IJERT/13.8.2020.2014-2022

Table 2: Types of openings in the Sana ani building. Source: Authors.

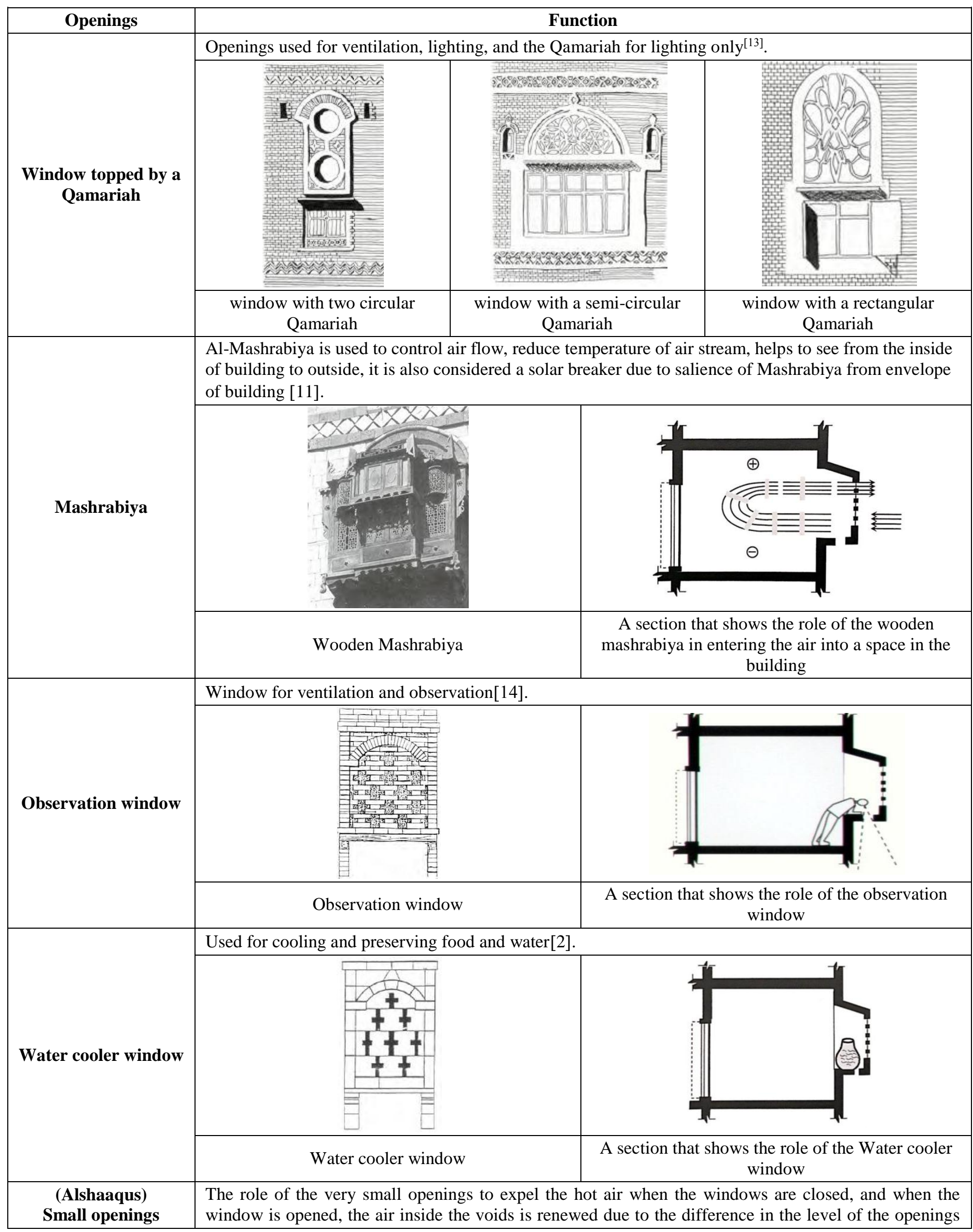


International Journal of Engineering Research and Technology. ISSN 0974-3154, Volume 13, Number 8 (2020), pp. 2014-2022

(C) International Research Publication House. https://dx.doi.org/10.37624/IJERT/13.8.2020.2014-2022

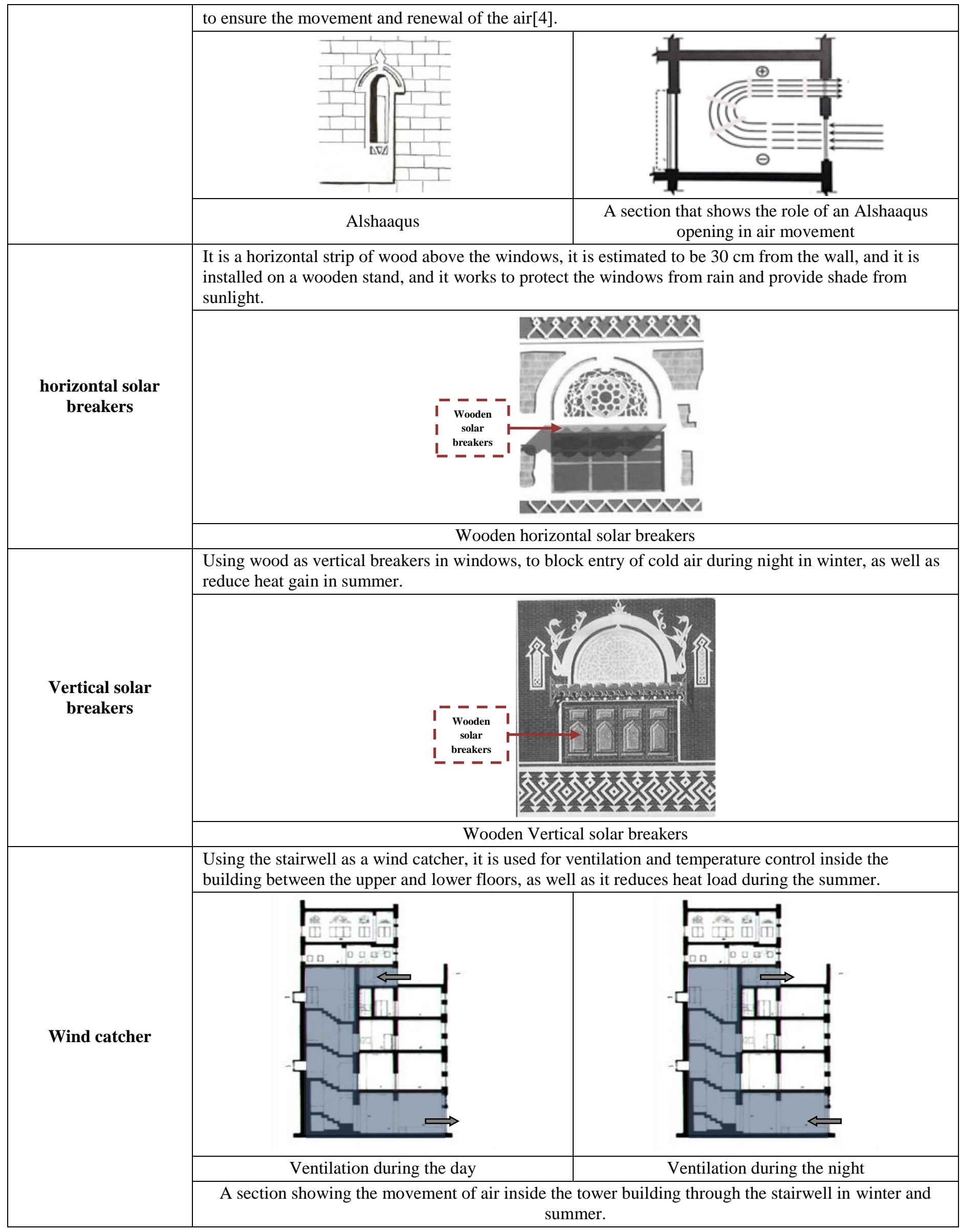




\section{II.IIII.Waste and pollution:}

In the field of waste minimization and pollution, traditional Yemeni architecture provided a complete picture of waste management. A closed stream has been created that ends with a sedimentation basin for drainage of sewage wastes in the back side overlooking garden, and use of wastewater after treatment to water crops, and solids are dried to be used as fuel for ovens or as fertilizer for farms [11] show (Fig.8).

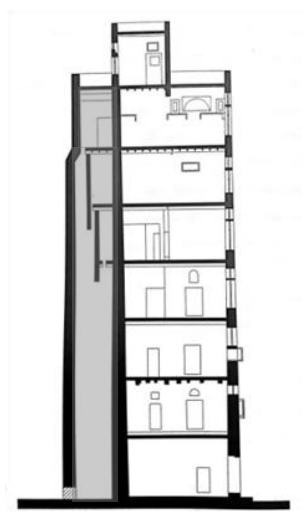

Fig.8: A section in the building where the drainage area is located. Source: Authors.

\section{CONCLUSION:}

- Yemeni architecture was formed on basis of its different environment due to terrain, which reflected construction pattern in each region and was shaped by local resources.

- The Yemeni man was able to adapt his architecture to surrounding environment, therefore the traditional local architecture automatically became a sustainable architecture.

- $\quad$ The Yemeni man used the surrounding natural resources in different areas to build his home.

- Buildings are designed to be energy efficient in a spontaneous way, by taking advantage of nature.

- Choosing materials that have a low impact on environment such as gypsum materials, studies have shown that it does not allow growth of fungi, and it helped to keep the balance of humidity inside building.

- Southern orientation in city of Sanaa worked to find a balance in temperatures in the summer and winter, as well as to find an acceptable level of thermal stability.

- The effectiveness of many elements and techniques in traditional sana'ani building, as it worked to achieve a comfortable environment for occupants of building, through openings that were thoughtfully placed in different facades, which achieved required balance of lighting control, ventilation and heat gain.

- The building materials that were chosen in traditional Sana'ani buildings do not affect environment, and when building is finished it returns to nature without affecting the environment, and thus the building life cycle was preserved from beginning of design until the completion of it.

- Study and understand applications and environmental elements in buildings through the style, elements and materials of the local building, which were used in the old buildings, and try to develop and benefit from them for any new building, in order to achieve the requirements and needs of the modern era.

Through the above, we recommend studying and understanding applications and environmental elements in buildings through method, elements and local building materials, which were used in old buildings, and trying to develop and benefit from them for any new building, in a manner that meets requirements and needs of modern era, in addition to working on the production of Modern materials , with same characteristics of old materials, and we also recommend research centers universities to develop Sana'ani architecture with contemporary architecture by applying them in building codes that can be used to produce new buildings.

\section{REFERENCES}

[1] Abdulla if Muhammad Ali, Samira Al-Shawash: "The effect of Climatic Conditions on the Architectural Character of Yemeni Cities: A Study of their Application to Cities - (Zabid, Sana'a, Shibam, Hadhramaut)". A research paper presented to the Third Housing Symposium, the High Authority for the Development of Riyadh. Kingdom of Saudi Arabia. 2007.p 65-66.

[2] Wael A. Mokbel. Ezzat A. Morghany, and. Shawkat A. Alkady." Urban heritage areathroughthescopeofgreen architecture concepts (the old city of Sana'a as a practical example)"Journal of Engineering Sciences, Assiut University, Vol. 35. 2007.p1051

[3] The city of Sana'a, the city of ShibamHadhramaut, the city of Zabid : Available at: http://www.yementourism.com.

[4] Muhammad Muhammad Al-Alolofi: "The characteristics of Yemeni architecture, its forms and directions of development ". Book, Ministry of Culture and Tourism, Republic of Yemen. 2004. P. 162.

[5] Sproul .J, Wan. M, and others:" Economic comparison of white, green, and black roofs in the United States". Article presented to Energy and Building journal .Volume 71.2014

[6] Abdul-Muttalib Ali, Samira Al-Shawash: "The effect of climatic conditions on the architectural character of Yemeni cities." Research paper presented to the Eighth International Architecture Conference, Architecture and Urbanism, Saudi Arabia. 2010

[7] Ashraf Al-Kibsi: "Local technologies and their role in achieving the economics of sustainable housing in Yemen." A research paper presented to the Conference 
on Technology and Sustainability in Urbanism, Kingdom of Saudi Arabia. 2010.

[8] Al-Taher Engineering Consulting Center: "The foundations of architectural design and urban planning in the various Islamic eras - an analytical study on the capital, Sana'a." Book. Organization of Islamic Capitals and Cities. 2005.

[9] Attia, Ahmed. "Traditional multi-story house (Tower House) in Sana'a City, Yemen. An example of sustainable architecture". Alexandria Engineering Journal. Vol 59. 2020.p 287

[10] Jamal ShafiqAlayyan: "Sustainability between traditional and contemporary architecture". A research paper presented to the Technology and Urbanism Conference. Kingdom of Saudi Arabia. 2010. p268

[11] Al-Sallal, Khaled. "Vernacular Tower Architecture of Sana'a". In book: Sustainability, Energy and Architecture, 2013. pp.257-287

[12] Abeer Ali: "Bioclimatic architecture and the environmental strategy for nature conservation, a new modern vision of old concepts." A research paper presented to the Technology and Urbanism conference. Kingdom of Saudi Arabia. 2010. p 11.

[13] Muhammad Imam, d. Dina Fikry, M. Anas is small. "Reviving the heritage of the old city of Sana'a in the shop design". Research paper submitted by the international design magazine. Part 8. 2018.261-262

[14] Attia, Ahmed. "Traditional Sustainable Architecture Techniques and Its Applications in Contemporary Architecture: Case Studies of the Islamic House in Fatimid Cairo and Sana'a, Cities in Egypt and Yemen" . World Academy of Science, Engineering and Technology International Journal of Civil and Environmental Engineering.Vol:13, 2019. p268-269 